aberration, or transmission of a tumour virus, and in no case was malignant disease recorded in tho mother during or before either of the pregnancies. The remaining consideration is whether the continuance of the pregnant state adversoly affects the progress of the cancer. This is a complicated question without any clear answer. Most would agree that it is necessary to judge each case separately on its merits.

If cancerous foci of microscopic dimensions are taken into consideration, the incidence of multiple primary malignant neoplasms is relatively high. Moertel ${ }^{18}$ writes, "The traditional concept of carcinoma as a single neoplasm intruding in an otherwise normal tissue is not always tenable. In a significant number of cases the initial nooplasm is only the first and most obvious manifestation of a carcinogenic process that may involve a large portion, or all, of a given tissue". Mersheimar, Ringel and Eisenberg's ${ }^{20}$ results suggest that second cancers arise in the same tissue or system more frequently than would be expected by chance where the first cancer was in the breast, skin, colon, rectum or genito-urinary tract. According to Moertel ${ }^{19}$, these findings should be taken into account in deciding the best treatment for cancers of these sites.

A series of contributions on the occurrence and treatment of certain uncommon or rare neoplasms are valuable for reference purposes. Of more general interest are papers on the relation between immune mechanisms and cancer and on the spontaneous regression of cancer. According to Grace ${ }^{21}$, the immunological impairment not infrequently observed in cancer patients ${ }^{22,23}$ is often related to disease directly affecting the lymphatic system. On the other hand, there are several examples of patients reacting immunologically to components or products of their own tumours; and the failure of advanced cancer patients to accept autografts of their own tumours is a puzzling phenomenon which needs further investigation. Everson's ${ }^{24}$ survey of examples of the spontaneous regression of cancer is superb and it would be fitting to conclude this article with his assessment of the significance of this phenomenon: "(1) The existence of spontaneous regression of cancer, in at least some cases, supports the concept of biologic control of cancer and reinforces the hope that a more satisfactory method of treating cancer than surgery, and/or radiation, may be found in future years.

"(2) The occurrence of spontaneous regression of cancer demonstrates the need for caution in the assessment of the value of chemotherapeutic and unorthodox therepeutic measures in isolated 'cures' of cancer.

"(3) The possibility of spontaneous regression of cancer must be considered in the evaluation of the prognosis of certain cancers. The remote possibility of spontaneous regression of cancer may be of some psychotherapeutic value in the patient with cancer which is not amenable to surgical and/or radiation treatment." F. J. C. RoE

1 Moss, N. Henry, Warren, S., Pack, George T., and 56 other authors. Ann. N.Y.Acad. Sci. 114, Article 2. Unusual Forms and Aspects of Ann. N.Y. Aad. Sci., 114, Article 2: Y Nusual Forms and Aspects of Sciences, 1964.) 7.50 dollars.

${ }^{2}$ Bloom, H. J. G., Ann. N.Y. Acad. Sci., 114, 747 (1963).

s Doland, E. M., Surg., Gynecol. Obstet., 44, 264 (1927).

Greenwood, M., Rep. Publ. Hlth Med. Subj., No. 33 (London: H.M.S.O., 1926).

s Nathanson, I. T., and Welch, C. E., Amer. J. Cancer, 28, 40 (1936).

- Egan, R. L., Ann. N.Y. Acad. Sci., 114, 794 (1963).

"Gershon-Cohen, J., and Borden, A. G. B., Ann. N.Y. Acad. Sci., 114, 782 (1963).

${ }^{8}$ Angevine, D. M., and Jablon, S., Ann. N.Y. Acad. Sci., 114, 823 (1963).

Brill, A. B., Tomonago, M., and Heyssel, R. M., Ann. Int. Med., 56, 590 (1962).

${ }^{10}$ Pifer, J. W., and Hempelmann, L. H., Ann. N.Y. Acad. Sci., 114, 838 (1963)

${ }^{11}$ Franks, L. M., Ann. Roy. Coll. Surgeons England, 14, 92 (1954).

12 Auerbach, O., and Stout, A. P., Ann. N.Y. Acad. Sci., 114, 803 (1963).

${ }^{13}$ Cutler, S. J., and Eisenberg, H., Ann. N.Y. Acad. Sci., 114, 771 (1963).

${ }^{14}$ Ermala, P., and Holsti, L. R., Cancer, 8, 673 (1955).

${ }_{15}$ Dargeon, H. W., Ann. N.Y. Acad. Sci., 114, 767 (1963).

${ }^{16}$ Willis, R. A., The Pathology of Tumours of Children (London: Oliver and Boyd, 1962).

${ }^{17}$ Gross, L., Proc. Soc. Exp. Biol., N.Y., 78, 342 (1951).

${ }^{18}$ Salaman, M. H., and Harvey, J. J., Nature, 191, 509 (1961).

${ }^{19}$ Moertel, C. G., Ann. N.Y. Acad. Sci., 114, 886 (1963).

${ }^{20}$ Mersheimar, W. L., Ringel, A., and Eisenberg, A., Ann. N.Y. Acad. Sci., 114, 896 (1963).

${ }^{22}$ Grace, J. T., Ann. N.Y. Acad. Sci., 114, 736 (1963).

${ }^{22}$ Grace, J. T., and Kondo, T., Ann. Surg., 148, 633 (1958).

${ }^{23}$ Southam, C. M., and Brunschwig, A., Cancer, 14, 971 (1961).

${ }^{24}$ Everson, T. C., Ann. N.Y. Acad. Sci., 114, 721 (1963).

\title{
BRITISH TECHNICAL CO-OPERATION OVERSEAS
}

$I^{\mathrm{N}}$ replying to a series of questions in the House of Commons on June 25, the Secretary for Technical Co-operation, Mr. R. Carr, said that he was charged to give the sort of help to the developing countries which they themselves said they most needed. British Embassies and High Commissions kept under review the progress and results of his Department's work, and specialist advisers and other staff from his Department made frequent tours overseas. The $£ 175$ million spent on overseas aid this year was a record figure and illustrated the rapid rate of expenditure over recent years. Consultation with the Agency for International Development in the United States was close and continuous. The 2,900 recruited under the auspices of the British Government in 1963 for service in the developing countries included a very small number not of British nationality; the 1962 figure was 2,300. Questioned as to alleged difficulties experionced by professional people in finding suitable employment on return to Britain from service overseas, $\mathbf{M r}$. Carr said that the Overseas Services Resettlement Bureau has been set up specially to assist members of the Overseas Civil Service retiring prematurely, and was doing so with outstanding success. His Department did all it could to encourage employers to release staff on terms which provide for their re-absorption and also to encourage general recognition that overseas service is of positive value in a professional career. $\mathrm{He}$ would welcome assistance in making the arrangements better known.

On Latin America, he said that more than $£ 500,000$ had been allocated from his Department's funds in this financial year compared with $£ 90,000$ in 1963, and this represented about 2 per cent of Britain's total bilateral technical assistance expenditure and about 20 per cent of that allocated to foreign countries. Much of the $£ 400,000$ allocated by the British Council to Latin America was also for technical assistance, and he hoped there would be 70 experts in Latin America by the end of the year. Britain could probably help most in agriculture and natural resources work and in technical education.

During the past 12 months, Mr. Carr said he had had requests for training in the United Kingdom of 20 Indians for maintaining and operating new plant to be installec. at the Durgapur Steel Works; for 4 engineering experts to assist the chief construction engineer; and for continuing the services of the British general manager until September 1965. More than 400 Indian steel workers had been trained in Britain, and Britain had also supplied substantial managerial and technical staff to the Durgapur Steel Works. Mr. Carr estimated that Britain's expenditure on technical assistance in Malaysia, excluding the Overseas Aid Service, would be about 50 per cent higher in 1964-65 than in 1962-63. 
On locust control, he said that the work of the AntiLocust Research Centre had become the basis for the international strategy of locust control. Two of the major types of plague locust had now been under control for more than 10 years and a third was at its lowest ebb for 24 years. The cost of killing a swarm of locusts had been reduced by 98 per cent compared with 20 years ago. The Centre had recently moved into new premises, which gave it greater scope. On the whole, research, including much field work, was done in Britain. Mr. Carr also referred to a startling and satisfactory increase in recruitment of teachers, which had risen by 300 per cent since his Department was established, compared with an average increase in recruitment of 80 per cent. Doctors still constituted a difficult field. Expenditure on bilateral assistance to foreign countries had risen by 170 per cent and was now 10 per cent of the total.

On research institutions in East Africa and the Caribbean, Mr. Carr said that the 27 such institutions in these regions employed about 250 senior and 350 supporting scientific staff and were doing most valuable work in medicine, agriculture and the development of natural resources. He had no specific proposals for increased grants before him at the moment, and his Department's research expenditure was now on a triennial basis. He estimated that his Department's expenditure on technical assistance to Pakistan was about $£ 650,000$ in 1962-63 and it would be about 20-30 per cent higher in 1964. $\mathrm{He}$ was somewhat disappointed at the initial response to the scheme of Commonwealth awards to university teachers. His Departmont employed or supported financially more than 1,200 research staff in research on problems affecting developing countries at a cost of about $£ 2$ million a year: just more than a quarter were in home-based units. Under the Low-priced Books Scheme, the university text-books series was available to 32 African countries and included technical and other text-books suitable for use in technical colleges. Preliminary investigations were being made of problems involved in extending the scheme to latin America, but no decision had been taken.

In a written answer on June 25, Mr. Carr gave the number of overseas students in full-time education in Britain in 1950 as about 12,500 , compared with 64,320 in 1963 , of whom 50,100 were from the developing countries. In January 1963, 2,600 teachers were serving in developing countries who had been appointed under the auspices of the British Government; just more than 1,300 were appointed in 1963 and more than 400 were sent out by other bodies, in addition to an unknown number recruited direct.

Also in a written answer on June 25, Mr. Carr gave the distribution of the 915 research workers overseas supplied by his Department, 643 of whom were in Africa, 142 in the West Indies and 108 in the Far East and the Pacific. Of these at December $31,1963,343$ were senior staff, 36 being directly employed, 18 supported 100 per cent, 251 between 50 and 100 per cent, and 38 less than 50 per cent supported. For the supporting staff, the figures were: 100 per cent, 10; 50-100 per cent, 485; and less than 50 per cent, 77. Twenty of those directly employed were in agriculture, including forestry; 2 in veterinary science; 5 in medicine; and 9 miscellaneous. Twenty-seven of those receiving 100 per cent support were in medicine. Of those receiving 50-100 per cent support, 383 were in agriculture, 41 in fisheries, 53 in pest control, 118 veterinary and trypanosomiasis, 99 medical, and 12 social and economic sciences. Of those receiving less than 50 per cent support, 30 were in agriculture, 49 in pest control, 4 veterinary science, 18 medical, and 8 social and economic sciences.

\section{DEVELOPMENT AND SUPPORT OF SYSTEMATICS IN BRITAIN}

$A^{T}$ present many universities are re-considering the teaching of biology and proposing a unified syllabus. A recent committee of the Royal Society has made certain recommendations on the place that taxonomy should take in the development of biology ${ }^{1}$. The Systematies Association (c/o British Museum (Natural History), Cromwell Road, London, S.W.7) has appointed a small committeo to consider the part the universities should play in this development. Members of the committee are: Prof. P. C. Sylvester-Bradley, Department of Geology, University of Leicester; Dr. V. H. Heywood, Hartley Botanical Labora. tories, University of Liverpool; Dr. P. H. A. Sneath, National Institute for Medical Research, London, N.W.7. The committee felt that in any consideration of university policy on systematies it is important to distinguish between tho broader field of systematies, which is concerned with the scientific study of the diversity and differentiation of organisms and the relationships which exist between them, and taxonomy, which is that part of systematics which deals with the study of classification, including its bases, principles, procedures and rules. Their respective roles in general biological courses and in the specialized training of taxonomists are different. The following aspects, although they interact with each other, should bo considered separately: (1) the teaching of systematics at the undergraduate level; (2) the training of taxonomists; (3) the promotion of research in systematics.

The role that systematics should occupy in undergraduate courses in biology has been hotly debated in recent years. Some university biology departments hold that everything that is not molecular biology or bioehemical physiology is 'systematics'. Thus such diverse fields as anatomy, morphology, palynology, ecology, cryptogamic botany, palæontology, populations genetics, etc., have been added to the responsibilities of the systematist. Partly as a consequence of these views, and partly as a result of the rapid expansion of the frontiers of biology into chemistry and physics, the expansion of systematics, not only to serve biology by the production and interpretation of classifications, but also to assume responsibility for the furtherance of several of its basic fields, has led to a situation that needs to be pondered by all biologists. Some experimental biologists feel that systematics has an insufficiently rigorous scientific basis, and have thus accorded to the subject a limited portion of the timetable. All too often the resources and staff allocated are quite inadequate for systematics to be carried out effectively. As a consequence many of the basic biological disciplines on which we depend for the consolidation of our factual information are in a state of neglect. The result of these attitudes is that it is becoming difficult to obtain suitably qualified staff in many fields, and this in turn leads to failure to apply modern techniques to these fields.

The point of view that theso subjects have been bypassed by modern developments in biology is untenable. Although anatomical investigations may lack the glamour of molecular biology, it is research in systematics which contributes to the advance in our knowledge of whole organisms and on which we ultimately rely for a full comprehension of the significance of biological science.

The importance of systematics in biological courses was considered at a meeting of the Systematics Association in Birmingham, on the "Place of Taxonomy in the Teaching of Biology"2. There the role of systematics as a focus for the integration of knowledge on biological diversity was stressed, and this, it must be pointed out, is quite inde- 